\title{
Sexuality and shifting paradigms - setting the scene
}

\author{
Yolanda Dreyer \\ Department of Practical Theology \\ University of Pretoria
}

\begin{abstract}
The social environment of the Biblical world can be distinguished in the Eastern Mediterranean (Semitic) and the Western Mediterranean (Greco-Roman) contexts. From a historical chronological perspective these contexts first functioned separately and then later merged because of Hellenisation. In both these Mediterranean contexts sexuality, religion and marriage were intertwined, but the values attributed to them, were different. The Old Testament mostly mirrors the Eastern Mediterranean world, whereas the New Testament represents a syncretism of the values of the Eastern and Western Mediterranean worlds. In order to understand the changes in the values attributed to sexuality, religion and marriage over time - from premodern, to modern, to postmodern times - it is necessary to investigate the social dynamics in the different eras. The aim of the article is to explore the nature of the interconnections and the values attributed to sexuality, religion and marriage in Biblical times.
\end{abstract}

\section{SETTING THE SCENE - THE INTERCONNECTION OF SEXUALITY, RELIGION, AND MARRIAGE}

Whether they like it or not, present-day Christian faith communities necessarily have to deal with three paradigms when considering any specific issue. This is true also for the topic of human sexuality. In the premodern Mediterranean world sexuality, religion and marriage were tightly woven together in the social fabric. The source book of Christianity, the Bible, is a document which originated in this world. Its perspectives on sexuality, religion and marriage are premodern. What was understood by these three concepts then differs from the understanding of the Modern Era. Today, evidence points to a radical shift yet again from the Modern to the Postmodern Era. In order to understand the changes in the values attributed to sexuality, religion and marriage over time, it is necessary to investigate the social dynamics of their 


\section{Sexuality and shifting paradigms - setting the scene}

interconnections in the different eras. The aim of the article is to examine the nature of these interconnections and the values attributed to them.

In South Africa a vigorous debate about changing perspectives on sexuality is taking place in church circles. An editorial of the newspaper with the highest circulation in the country, penetrates to the heart of the debate when posing a question as to the commonalities and dissimilarities of the political and the ecclesiastical debates on sexuality (Du Plessis 2005:ivNuus). For the author the difference between politics and church is obvious. The political perspective is that of proper policy for coping with the present social reality, whereas the perspective of the church is about what, according to the Bible, is proper with regard to sexuality. However, there is some common ground:

One important factor is underlying to both: change and how organisations, institutions and individuals deal with it ... Charles Darwin's important premise of evolution is inexorable and impacts on both the church and the ANC: it is not the fittest or the most capable of the species who will survive, but those who best adapt to change.

I would not trade where I am today for anything in the world: being part of a language community in a country which is dynamic and changing. What a great time to be alive.

(Du Plessis 2005:ivNuus)

In the process of socialisation, rules for living are given and internalised.

Socialised norms do not change easily. Those norms which serve to retain the balance of power, change even more slowly. The reason is that those who have power, protect their interests. Examples of such slow change are the shifts from aristocracy to democracy, changes in social roles pertaining to patron-client relationships, as well as changes in honour and shame codes. As was the case in the premodern Mediterranean world, so gender and sexuality were also embedded in honour and shame codes in the Modern Era. Changes related to issues of gender and sexuality generally take place very slowly. Only when socialised norms have changed, will it be possible to recognise that inherited (from the premodern Bible and the Modern Era) perspectives on gender and sexuality are at odds with today's world. Only when power relations have changed, will it be possible to view gender and sexuality from a new perspective. To acknowledge that changes in the social interconnectivity of sexuality, religion and marriage which have already taken place and are still taking place, is the challenge to the church today. The accompanying values have also changed. 
The interconnection of sexuality, religion and marriage is part of the processes of institutionalisation and deinstitutionalisation (see Dreyer 2002:625-641). These processes pertain to socialisation, legitimation and normalisation. The social sciences focus on constitutions, legal systems and social conduct as expressions of the legitimation of power interests. Theology, on the other hand, is interested in how power is expressed through the process of canonisation, which is the inscripturation of religious norms. This entails the mystification of social roles, whereby divine symbols are used to legitimate social constructs (see Berger \& Luckmann 1967:92-95).

Though symbols are abstract and transcend the social world, the language of symbolism is borrowed from the social world. For example, if God is called "Father", it is not an ontological statement about the nature of God. It is a metaphor which aims to express an analogy between what is ultimate in the symbolical world and what is ultimate in the social world. "Father" was a god-like figure in the premodern Mediterranean world (see Hamerton-Kelly 1979:38). The metaphor of God as father is expression of an ultimate social value from a particular environment attributed to a figure of highest meaning. For example, with reference to God's so-called "identity-crisis" in Ezekiel 23 on account of the Babylonian exile, the Old Testament scholar Mary Shields (from Trinity Lutheran Seminary in Columbus, Ohio) says:

\begin{abstract}
Using conventions associated with gender and sexuality, this text seeks to address YHWH's power and authority. In the end, YHWH does (re?)establish control over the people, thereby shoring up his own identity as proper male head of household, which in turn proves his sovereignty as deity. The power of using sexual imagery is that the conventions governing gender and sexuality are almost taken as a "given" in any culture, or, in other words, "the way things ought to be".
\end{abstract}

(Shields 2001:129)

Also the words about God in the Decalogue are not devoid of sexual imagery: "You shall not make for yourself a graven image ... you shall not bow down to them or serve them; for I the Lord your God am a jealous God ..." (Dt 5:8-9).

However, Judy Brown (2004:289) argues from an evangelical point of view that the "fact that humanity bears the image of God cannot be turned into the notion that God bears the image of humanity." According to Brown, the above-mentioned prohibition in Deuteronomy not only denounces wrong action, but also the wrong thinking about God. She is of the opinion that it is "wrong to confuse God's nature with the nature of physical, created beings. And perhaps there is no characteristic more distinctly physical than sexuality." 


\section{Sexuality and shifting paradigms - setting the scene}

Then again, according to the renowned biblical scholar, Gerhard von Rad ([1964] 1966:57), the historical context of those addressed by Deuteronomy was polytheism, in other words a context of fertility religions. Central to the prohibition in the Decalogue is "Yahweh's zeal which insists on his being the only one for those who belong to him." The concept of "belonging to" is sexual imagery from the fertility culture. This kind of imagery expresses "male envy". In his book, Male envy: The logic of malice in literature and culture, Mervyn Nicholson (1999:7; emphasis by Nicholson) makes the following remarks about "Male Envy" as a social phenomenon:

The code of male envy is not so much a "code" in the sense of a set of rules as it is an ethos, an encompassing current of values and assumptions. Still, a number of configurations are identifiable, even predictable, in its scene. At the center is the compete/control hierarchy, as it may be termed. This is a scale of power; on it, individual males compete with one another for control of objects and domination of other competitors, hence "compete/control." There are different versions of the compete/control hierarchy, depending on specific context, but they operate on similar lines, and to that extent are the same. Thus, one rises on the compete/control hierarchy by gaining power points - markers - for example: victories over competitors, displays of prestige, monopoly over power objects (i.e., objects that facilitate power over others or enhance ego, especially money and weapons, sometimes sacred arcana or technological artefacts), and other emblems of control, including desirable women, or the bodies of defeated enemies, whether metaphoric or actual ... In other words, the "origins" of Male Envy are not a matter of myth or primeval speculation, or neolithic ritual, or testosterone; but a way of thinking rooted in a social system, one that has a specific history as well as specific social dynamics.

It is clear - as the dialectical-theologian Paul Tillich (1957:14-18) emphasised - that cultural questions "determined the contents of theological answers" (Thatcher 1999: 21). In this vein James Nelson (1992:115-116) distinguishes between "sexual theology" and the "theology of sexuality". Adrian Thatcher (1999:20) explains the difference: "The latter concerns itself with the Bible and tradition as these deal with sexual questions. These findings are then applied to contemporary sexual dilemmas and problems. But sexual theology begins with our experience as embodied, sexual beings." According to Nelson (1992:21), the "movement must be in both directions, not only one." Thatcher (1999:30) speaks of a "loyalty to experience". It "requires giving priority to the testimony of contemporary men and women in the area of sexuality, and 
being willing to rethink the adequacy of premodern and modern institutions and assumptions which have regulated family and sexual life in the past." $\mathrm{He}$ also speaks of the "loyalty to the people of God", and this "requires the process of making available to them the resources of the Bible and tradition as they might be understood by an encounter with postmodern experience and culture." This "encounter" calls for an acquaintance with the social environment of the Bible.

The social environment of the Biblical world can be distinguished in the Eastern Mediterranean (Semitic) and the Western Mediterranean (GrecoRoman) contexts. From a historical chronological perspective these contexts first functioned separately and then later merged because of Hellenisation. In both these Mediterranean contexts sexuality, religion and marriage were intertwined, though the values attributed to them, were different. The Old Testament mostly mirrors the Eastern Mediterranean world whereas the New Testament represents a syncretism of the values of the Eastern and Western Mediterranean worlds. How this manifested, will now be briefly described.

\section{SEXUALITY IN THE FIRST-CENTURY EASTERN MEDITERRANEAN SOCIAL WORLD}

Every society has a status system as part of its cultural rules. According to this system privileged people (those with status) have access to resources and the disprivileged are debarred from controlling and consuming resources. In societies of patrilocal residence the males remained near their place of birth, resulting in a core of closely related male residents, supplemented by wives drawn from neighbouring communities. The women were outsiders. Power and prestige were located with the men (Burton \& Whiting 1961:89). In the first-century Mediterranean family the central position belonged to the father. Beyond the family was the village, beyond the village the city, and beyond the city, the ends of the earth. This understanding of society served as an analogy for the concept "kingdom of God" (Scott 1990:79). The father was seen as God's representative. He was to ensure that God was worshipped and obeyed. Belonging to a family was a prerequisite for receiving God's blessing. Within the family, the father's status was divinely ordained (see Hamerton-Kelly 1979:27). In this way the divine and the human met at the most intimate level of family.

The nature of gender roles correlated with the "division of honor into male and female" (Malina 1993:48-55). Women's "exclusivity" was defended by the males. Male honour was symbolised by the testes. The role of the father was to exercise authority over the family and to defend its honour. Female honour, symbolised by the hymen, related to sexual exclusiveness, 


\section{Sexuality and shifting paradigms - setting the scene}

reserve, caution, modesty, and timidity. The mother's sexual purity was primarily the concern of her husband, but also of her male children. All the males were to guard the purity of their daughters and sisters. The role of the father of a household was not only to beget children, but also to provide for and protect the family (cf Matthews \& Benjamin 1993:8). Being born into a family did not automatically make the child part of the family. In order for the child to really belong, the father's decision to adopt the child into the household was pivotal (cf Matthews \& Benjamin 1993:10). This acknowledgement of the father, rather than the birth itself, was the beginning of life for a child. The father exercised the power of life and death over his offspring and was a "god-like being."

The primary, gender-specific role of the mother of the household was childbearing. She was also responsible for ensuring that the other female members of the household regularly bore children (cf Matthews \& Benjamin 1993:25). The other role of the mother, that of manager of the household, was not gender-specific. The responsibility for ensuring that everyone was fed, required careful stewardship of the resources of the household. This necessitated absolute control on the part of the mother over those areas for which she was responsible (cf Matthews \& Benjamin1993:25). Yet another role of the mother was that of teaching the women and children. This responsibility was taken over by the father once the boys became young men and participated in the communal labour of the village. By story telling, the mother transmitted the traditions of the community to her children. She taught them wisdom (cf Matthews \& Benjamin 1993:28-29). Typical female behaviour included taking the last place at the table, serving others, forgiving wrongs, having compassion, and healing (Malina 1993:54).

In patriarchal societies it was commonly believed that the presence of a male would prevent a woman from bringing shame on the family. When a husband was absent, the wife had to obey the wishes and instructions of other males. This resulted in close social scrutiny. Though the man was absent, he would remain present to his children through his wife who acted as his authorised agent. She was responsible for protecting her husband's interests.

When simple agrarian societies developed into advanced agrarian societies, kinship ties were still important, though no longer the "chief integrating force" (Lenski, Lenski \& Nolan [1970] 1995:213). The extended family (the beth-av) had by then slowly broken up (see Fiensy 1991:132). The Hellenistic society was different. Whereas Eastern Mediterranean peoples had lived in extended family units, subsisting through communal labour on isolated farms, the people of the Western Mediterranean lived in nuclear families and worked on large estates (see Fiensy 1991:121). Families had disintegrated 
because their "agroeconomic" base was removed (see Wolf 1966:15). One way of dealing with this situation was by increasing production. However, this strategy would need more labour, which would make it not worthwhile. Other possibilities of supplementing their income would be by working as seasonal day labourers or finding temporary work in the fishing industry, or as craftsmen (see Fiensy 1991:95).

Where previously the family was a viable economic unit, now it was the village. Neighbours worked together as a socially supportive unit (Fiensy 1991:135; cf Harper 1928:106). Villagers were generally related to one another by ties of blood or marriage. In Israel matters of sexuality, including marriage arrangements, were linked to the temple cult's codes of holiness and its "classification" of people. This meant that "holiness was understood very specifically as "separation" (Borg 1987:86):

To be holy meant to be separate from everything that would defile holiness ... Holiness became the Zeitgeist, the "spirit of age," shaping the development of the Jewish social world in the centuries leading up to the time of Jesus, providing the particular content of the Jewish ethos or way of life. Increasingly, the ethos of holiness became the politics of holiness.

(Borg 1987:86-87)

Whoever was considered a nobody according to this politic of holiness, would have no identity, which in turn would lead to strained relationships with villagers and even family.

Calling God the "father" of all, as Jesus and Paul did, would be to redefine the entire system of holiness and the importance of patriarchy, since it represents a different understanding of who God is and who human beings are. In order to fully understand the impact of this, the marriage arrangements according to the ideology of the Jerusalem cult, should be investigated.

Israel was a temple state and its policies were determined by the purity ideology of the Jerusalem temple cult - an ideology that marked Israelite society as patriarchal, exclusivist and hierarchical. Familial, political, economic, and religious life were tightly woven together. Every household of a "son of Abraham" was regarded by the Pharisees as a replica of the temple (see Neusner 1973:75; cf Elliott 1991:102-108). Even the design of the house was modelled on the temple. Women and children were limited to their quarters, just as in the temple. Regulations concerning meals (see Neusner 1979:47), together with the dietary and purity prescriptions, transformed households into "holy places". 


\section{Sexuality and shifting paradigms - setting the scene}

The conventional wisdom, which formed the consciousness of the people, was contained in the Torah. Sexuality and marriage regulations were determined by the temple and rules about permissible sexual relations were derived from the Torah. The interests of the head of the household, the father, were the motivating factor for all marriage arrangements.

Marriage regulations were related to the way in which society was organised. There were three types of marriage strategies (see Malina 1993:159-161), namely the "reconciliatory," the "aggressive", and the "defensive" strategy. They can be broadly linked to three successive periods in the life of Israel: the period of the patriarchs, the period of the kings, and the post-exilic second temple period. The reconciliatory strategy is evident in the patriarchal-immigrant period. Abraham emigrated to Canaan, which was already inhabited by people grouped in city-states which were ruled by kings. Marriages were endogamic, which meant that the spouse had to be from a person's own family. Abraham married his half-sister (Gn 20:12); Nahor married his brother's daughter (Gn 11:29); Isaac married his father's brother's (his uncle's) son's (his cousin's) daughter (Gn 24:15); Esau married his father's brother's (his uncle's) daughter (his cousin) (Gn 28:9); Jacob married his mother's brother's (his uncle's) daughter (Gn 29:10); Amram, Moses' father, married his father's sister (his aunt) (Ex 6:20; Num 26:57-59).

"Sexual hospitality" characterized the patriarch-immigrant period. Women were "offered" to others for the sake of the attainment of higher social status and economic advantage. Abraham, for instance, offered Sarai to the Pharaoh for the sake of economic advantage (Gn 12:14-16). Lot offered his daughters, in the presence of his future sons-in-law, to the men of Sodom for the sake of the honour of his guests (Gn 19:6-9). The eldest and youngest daughters of Lot's children (according to legend the ancestors of, respectively, the Moabites and Ammonites) were sired by Lot himself (Gn 19:31-38).

Abraham offered Sarai, his father's daughter, in order words, his half-sister, to whom he was married (Gn 20:12), to king Abimelech of Gerar for the sake of privilege in a new country (Gn 20:1-18). Jacob was prepared to overlook the rape of Dinah, his daughter with Leah, by Shechem, although Dinah's brothers, Simeon and Levi, took revenge (Gn 34:30-31; 49:5-7). On the other hand, Reuben dishonoured his father Jacob (Israel) by committing incest with Bilhah, Jacob's slave wife (Gn 35:21-22; 49:3-4). In this period polygamy was customary. We read in this regard about Abraham (Gn 16:1-4; 25:1-6), Isaac (Gn 24:67), Esau (Gn 20:34; 28:9) and Jacob (Gn 29:21; 30:12) who were married to more than one wife.

In the pre-exilic monarchical period, the reconciliatory strategy gives way to the aggressive strategy. The story of Shechem's rape of Dinah, which 
was avenged by her brothers, is already an indication of this. Fathers attempted to choose spouses who were part of the "family of orientation", in order to keep their daughters in the family. The collective family honour was strengthened in this way. The family did not lose its daughters. According to patrilocal custom, the sons, on the other hand, were encouraged to marry women who were not related to the family. In this way the family could be strengthened by gaining new members from the outside. Marriages were part of a competitive (agonistic) society in which the heads of families aggressively attempted to attain greater geopolitical power at the cost of outsiders. This strategy presupposed polygamy and the ruthless authority of the head over his family. Examples of this strategy are king David (see $1 \mathrm{Sm}$ 25:39-43; 27:3; 2 Sm 3:2-5) and, especially, king Solomon (see 1 Ki 11:1-5). However, having too many wives from unrelated tribes ("families of orientation"), resulted in conflicting interests. The stories of Solomon (1 Ki 11:1-3), Rehoboam (1 Ki 14:21-24) and Asa (1 Ki 15:11-14; 22:46) prove this point. During this period "sexual hospitality" was seen as an assault on the honour of the man. Married women as well as unmarried daughters belonged to the domain of the man. Adultery was viewed as a serious offence against the authority of the man to whom the woman "belonged". The seduction or rape of an unmarried girl no longer lead to the violator having to marry her, as it was in the time of the first strategy. Now the decision was up to the father (Dt 22:23-27), while the brothers would certainly take revenge (Gn 34:30-31). Divorce could be arranged on the basis of an agreement between men (see Dt 24:1). According to this regulation, the former husband lost all rights over the woman. He could not take her back and she was free to marry again. Only men were legal entities. However, widows and unmarried divorcees could also enter into judicial agreements. "Sexual hospitality" was prohibited (Dt 24:4). The objections of the prophets to temple prostitution related to this former practice (Hs 4:14-19; Jr 5:7-9; Ezk 16:22).

During the post-exilic second Temple period, marriage regulations were determined by cultic purity regulations. Only marriages within the own group of families, the "family of procreation", that is, the "house of Israel", were permitted (see Malina 1996:50). Through marriage the "holy seed," that is, the physical "children of Abraham" could continue (see Malina 1993:137-138). The practices of circumcision and admission to the temple as the place of God's presence were related to this view. Marriage reform regulations (Neh 910; Ezra 9:10) were meant to achieve the dissolution of undesirable "mixed marriages" (see Bossman 1979:32-38).

For the purposes of marriage arrangements people were classified from holy to less holy to impure (see Jeremias 1969:271-273). This 


\section{Sexuality and shifting paradigms - setting the scene}

classification determined who could marry whom and who could enter the temple. A priest was forbidden to marry a woman who had already "belonged to a man", such as a widow, a divorcee, or a woman who had been raped. Those born eunuchs, those with deformed genitals and hermaphrodites could not marry at all, since they could not contribute to the continuation of the "holy seed," the "children of Abraham". Those outside the covenant were deemed "impure" and could not proceed further than the temple square, the "court of the Gentiles". They were to live as though God did not exist (see Sanders 1993:229). Not being children of Abraham meant that they could also not be children of God. Men in this category could only marry "impure" women (including Gentiles) or were to remain unmarried. In a society in which the honour and social identity of a man, were determined by his status as a member of the family of Abraham and his contribution to the physical continuation of that family, being unmarried had serious implications.

\section{SEXUALITY IN THE FIRST-CENTURY WESTERN MEDITERRANEAN SOCIAL WORLD}

In Greco-Roman sexuality same-sex relationships between and an older and a younger man were common. Whereas the sexual union with a woman was necessary for procreation, the same-sex unions of men were seen as the "highest form of love" (Garton 2004:32). Some scholars (Halperin 1990; Winkler 1990:45-70; Veyne 1985:26-35) contend that the focus was on activity or passivity of the sexual partners, rather than on their orientation of "homosexuality or heterosexuality". The active partner would be the one with the higher status, whereas the passivity of the other partner in sexual interaction would mirror his or her lower status in society. However, scholars, such as David Cohen (1991:171-202) and John Thorpe (1992:54-61), argue for the existence, already in antiquity, of the phenomenon of innate "homosexuality" (even though this term is derived from a later era), which goes beyond the pederastic relationships, known to that culture. Thorpe (1992:54-61; see Garton 2004:39) refers to three categories of "sexual orientation" in antiquity, namely "gay, lesbian and straight", in other words categories similar those known and used today.

In general it can be said that Greco-Roman societies were driven by competition for power and dominance. Sexual activity mirrored this. Social status, rather than gender, determined sex roles (see Winkler 1990:45-70). Only males could be full citizens and were fully sexual subjects. Women found themselves on the margins of society. Because of his status, the male citizen was supposed to be the active partner in sexual encounters, be it with a male or a female person. Being the passive one in a sexual encounter meant to 
symbolically submit to authority. That is why, for instance, men raped other men (cf Allen 2000:214-215). Garton (2004:33) puts it as follows: "Enforcing sexual submission or humiliation was a means of asserting dominance ... Thus there were very specific sanctions against sex between male citizens of the same status because these threatened codes of masculine dominance."

There was some ambivalence as to a relationship of a citizen with a freeborn boy who was to become a citizen later in life. On the one hand the pederastic relationship was romanticised, but on the other hand is was criticised and mocked. Boys were generally urged to resist relationships with older men. It was feared that they would not be able to make the transition from the passive one to the active one when they were fully matured. Another concern was that these relationships would compromise social bonds later when the youth had become a full citizen and the two previous sexual partners would be equals. During the Roman period there was a movement to promote control and abstinence in the interest of "self-mastery and a means of preserving the body from the ravages of indulgence" (Garton 2004:36; contra Cantarella 2002viii-ix).

Women were confined to the home. They had no role in public life and developed their own private social networks. They raised the future citizens and transmitted culture to the next generation (see Rawson 1992). Wives generally had (full) authority in the homes and the functions they fulfilled were appreciated by their husbands.

Sexually women, regardless of their social status, were always the passive ones yielding to male dominance. On the other hand women's sexuality was also feared, more so in the Roman world than in the Greek. Language illustrates this: a word common to Greek and Latin moecha/moicha meant adulteress in Greek, whereas in Latin it referred to a sexually dominating woman (Garton 2004:37; see Foley 1981; Cameron and Kuhrt 1983; Cantarella 1987). Tribades was the word referring to women who were said to penetrate women and men, and they were feared in both Greek and Roman cultures (Halperin 1998:353-354). Though women were severely limited in their sexuality within the dominant male culture, some ancient Greek and Roman legal texts do suggest that they were able to exercise a measure of agency (see Foxall 1998:132-133; Cole 1984:111-113). Though there is not much literature on female same-sex love, the works of the Greek poet, Sappho and the Roman poet Sulpicia do attest to female homoeroticism in antiquity (see Winkler 1990:129-209). Legal references to women "lying with each other" have been found. This indicates that women did have permanent of semi-permanent relationships with other women (Garton 2004:38; see Foxall 1998:132-133; Boswell 1980:220-221; Boswell 1994:71). 


\section{Sexuality and shifting paradigms - setting the scene}

In the medical literature of antiquity two perspectives on gender were prominent: the Hippocratic view that women and men were totally different beings, and the Aristotelian view that women were underdeveloped men and, therefore, inferior beings. The latter view gradually became the dominant one (Garton 2004:38; see Dean-Jones 1994:225-229; King1998). The second century Greek doctor, Galen (see Garton 2004:38), subscribed to the Aristotelian idea that women and men shared one body-type, but that the bodies of women had not developed sufficiently. For Galen the difference was caused by body heat: men had sufficient heat to develop fully, whereas women were cold, their bodies "moist and imperfect" (in Garton 2004:38). This was the prevalent idea about the sexes up to the late 1700's (see Laqueur $1990: 25-62$ ). The consequence of this way of thinking was that maleness and femaleness were not seen as fixed. If men were inactive, they were in danger of becoming feminine and if women were very active they could generate sufficient heat to become more masculine. Social control was needed in order to maintain some stability and to protect vigorous, dominant male sexuality: "[T]his necessitated a complex sexual and social regime to produce and perpetuate masculinity" (Garton 2004:39).

Men who were passive or effeminate were a danger to the position of male citizens being the strong, dominant persons in society. Effeminacy in men therefore threatened the stability of society and its moral codes. A boy was regarded as beautiful when he "manifested the acme of masculinity" (Foxall 1998:134-135).

The kinaidoi and cinaedi were a group of men in ancient Greek and Roman cultures respectively who chose to be the passive partners in sex. Not all men, however, had a choice. Defeated warriors, for instance, were forced into the humiliating position of being sexually dominated (raped) by the victors (Gleason 1995, 1990:389-415). Another group in ancient Greek society was called androgynoi. They were still acceptable to society, but were on the border of effeminacy. They could be distinguished from other male citizens on account of traits such as "softness, slack limbs, mincing steps, a shifting gaze tilted heads, upturned palms and thin shrill voices" (Garton 2004:42). Though initially having different meaning, the terms cinaedi and androgynoi were later used as synonyms. According to Amy Richlin (1993:523-573; cf Richlin 1992a, 1992b) these men were objects of gossip, ridicule, abuse, ostracism and other social punishments (cf Pellegrini [1992] 2001:47). They formed a subculture in ancient society which can be equated with today's "homosexuals" and were treated with what is today called "homophobia" (see Blumenfeld [1992] 2001). David Halperin (1998b:93-120 see also Gleason 1990:389-415; Williams 1999:160-224) strongly disagrees with Richlin. For 
him there is a distinction between cinaedi and homosexuality. Cinaedi were demeaned and punished because they threatened gender identities, not because of the gender of their sexual partner. He also disagrees with her application of the term "homophobia" to the persecution of the cinaedi in antiquity, implying that they were treated badly because of their homosexuality. For Halperin (2002:87-124) "homosexuality" and "homophobia" as the terms are understood today, are not applicable to ancient Greek and Roman cultures. Whether he engaged in sexual activity with a woman or with a man, the active partner was never demeaned, ridiculed or persecuted.

According to Garton (2004:45) "[w]hat is most important in antiquity is the challenge to gender stereotypes. Thus seeing these subcultures as homosexual is not only anachronistic, it also distorts the real nature of the social pathology that concerned the ancients." Their chief concern was with activity or passivity, which could of course be seen differently. When exactly would a partner be active and when passive? Central to making this distinction, is what was regarded in ancient times as the "proper" use of the phallus (Williams 1999:91-93), namely the direct and purposeful use of the phallus, such as penetrating some orifice or other. Which orifice it was and to whom it belonged was not important, since the concern was not with procreation, but with being active. According to Garton (2004:45) the phallus was "a potent signifier in many (if not all) cultures." Though it functioned differently in different ancient phallic cultures, it always contributed to structuring sign systems and language, and regulating sexual customs and rules of conduct in society.

Garton (2004:46) points out the post important difference between sexuality in the ancient cultures of the Western Mediterranean and modern Western cultures:

In modern Western cultures what is most troubling about homosexuality is the gender of the participants in the sex act, not what acts they perform (oral, anal, fetish, masochistic, sadistic and so on). Similarly it is irrelevant in modern culture whether one penetrates or is penetrated in the homosexual act. But these distinctions are crucial in ancient Athens and Rome. There the gender of the sexual partner is of less concern and the type of act of paramount importance.

This difference if important if there is an honest attempt to understand expressions of sexuality, their meanings and significance within their cultural contexts. If such understanding is reached, it will prove impossible to distil 


\section{Sexuality and shifting paradigms - setting the scene}

timeless values and norms about sexuality and marriage from the Bible to be applied directly to modern and postmodern situations.

\section{MODERN AND POSTMODERN VIEWS ON SEXUALITY}

Today contemplation of an issue such as sexuality is still informed by knowledge gained through modernist means. This includes psychological insights from Freud onwards (see, inter alia Freud's [1938] work "Infantile sexuality"). In Michel Foucault's ([1976] 1978) History of Sexuality, Volume 1, the starting point of a "historiography of sexuality" (see, inter alia Beukes 2002:283-298) is the engagement with the insights of Sigmund Freud. This "point of entry" (Garton 2004:10) represents a critique of the "essentialistic" (see later) aspects of psychoanalysis. This critique was triggered by Steven Marcus' (1966) distinction between Victorianism and modernity. Foucault (1978:194-228) argues that Marcus has it wrong when he says that Freud helped modernity to leave Victorianism behind. Instead, Freud's heritage is that modernity's view on sexuality is still very much essentialistic and that Victorianism did not repress sexuality, "but instead produced it" (Garton 2004:11). Together with Freudian psychoanalysis, psychological insights from figures such as Richard von Kraft-Ebing (see Padgug 1992:43-67), Havelock Ellis (see Weeks 1989:141-159), Magnus Hirschfeld (see Weeks 1989:152156) and later studies by Alfred Kinsey (see, inter alia, Kinsey, Pomeroy \& Martin 1948) and William Masters \& Virginia Johnson (cf Beukes 2002:291; Stone 2000:233) helped form the modern idea of sexuality, which also includes biological, genetic and socio-genetic insights. The methods and findings of modern research in the field of sexuality are not homogeneous (Stone 2000:233; see Robinson 1996; Bland \& Doan 1998). However, according to Stone (2000:233), the following features can be distinguished:

- $\quad$ emphasis on the biological and physiological aspects of sexuality;

- $\quad$ the focus on sexuality as an instinct, which is therefore universal rather than socially determined;

- $\quad$ the idea that sexual behaviours can be classified in accordance with specific psychological character types;

- $\quad$ an essentialist perspective on "male" and "female" sexuality.

The anti-essential postmodern approach to sexuality is based on a "constructionist" view of sexual identity. According to Müller \& Pienaar (2003:140), such an approach does not view "[o]ne relationship [as] a carbon copy of the next." This "realisation", according Müller \& Pienaar (2003:140), "does away with so-called objective uncontextualised knowledge about wrong 
or right sexual conduct in relationships." Anti-essentialism opposes the idea that people "have a timeless, universal core which ultimately explains their actions" (Ward 1997:136). Sexual identity is a cultural rather than a natural or essential category. Glen Ward (1997:136) states that, because of essentialism's attempts to define people's "proper sexual place in terms of what is supposedly natural, it has become important to dispute the way in which society habitually calls upon an idea of 'nature' as the ultimate explanation of things which happen within culture." According to Ward (1997:136), an anti-essentialistic social-constructionist starting-point can lead to the following two very different approaches, the one deterministic while the other emphasises agency and choice:

- Instead of being born with a particular in-built substance, we become what we are through being acted on by a series of social factors. You are constructed by the social and are ultimately determined by it.

- We can more or less freely fabricate our identities for ourselves. We have a degree of choice about how to represent ourselves.

Ward's (1997:137) position is that "personal identity is formed out of the tension between the two, and that this tension can manifest itself in different ways as we enter different circumstances. Postmodernists would reject any attempt at a single, unified and universal theory of selfhood and would look instead at how the determined and the free versions of self construction interact with and affect each other in variable ways according to our changing social situation."

\section{SEXUALITY IN TODAY'S WORLD}

The anti-essentialistic perspective has heightened awareness that a religiousbased approach to issues of sexuality has not been open to the results of recent biophysical research. However, these insights have shaped social attitudes and therefore cannot be ignored. Increasingly, when dealing with present-day issues, faith communities are challenged to take note of the findings of the natural and social sciences. Today postmodern thought is making inroads into the social world, including faith communities. As far as sexuality is concerned, postmodern criticism levelled against modernity's ahistorical, biologically and psychologically "essentialistic" views. This criticism has challenged the discussion to include the "thoroughly social, cultural and historical conceptualization and constitution of sexuality" (Stone 2000:235).

Contributions have come from different fields. From sociology and psychology the insights have come that sexual behaviour is the result not only 


\section{Sexuality and shifting paradigms - setting the scene}

of biology, but also of a complex mixture of cultural symbols and role expectations in dialogue with intra-psychic scripting and internal dialogue (Stone 2000:235; cf Gagnon \& Simon 1973; Simon 1996). Anthropology has demonstrated that sexual practices and their meanings vary substantially across different cultures. This has brought the validity of general and generalising statements about sexuality into question. Biological and psychological determination have had to make way for views which take the impact and meanings of socio-cultural organisation and interpretation seriously (Stone 2000:235; see Herdt 1997; Caplan 1987; Vance 1989; 1991 : 875-884). Historical analysis pointed out over a period of time differences will occur within one culture. As social aspects such as kinship, gender relations, ideologies, demographic changes, mobility, occupations, class relations, ethnicity change, sexuality takes on different forms and meanings (Peis \& Simmonds 1989; Weeks 1985, 1986, 1989; D’Emilio \& Freedman 1997; Seidman 1990; Giddens 1992).

In theology, ecclesial institutions are challenged by critical theory to take into consideration:

- that "revelation" should be understood contextually,

- that canonisation should be subjected to demystification,

- $\quad$ that the interconnectivity of sexuality, religion and marriage should be deconstructed,

- $\quad$ that the "rule of the phallus" (male domination) in sexuality, religion and marriage should be actively deconstructed and opposed by the church in attitudes, behaviour and deeds.

This challenge for theologians and ecclesial authorities is to embrace the shift from an exclusivity (patriarchal) to inclusivity. The South African philosophertheologian, Johann Beukes (2002:297), "rephrases" Michel Foucault's insights as follows (my translation from the Afrikaans):

Not only have new spaces been created because of the decentralisation of the phallus, but a radically new sexual identity has also been formed: androgenic sexuality, from which polyform sexual identities ensue ... However, the open circle of radical discretion offers and guarantees a private space for these identities [including "androgenic subjects and polygenic subjects such as the queer, the cross dresser and the transvestite"], unconditionally, without discrimination, without pre-judgment - because each sexual condition is kept quiet and non-public. 
Creating privacy because of the virtue of inclusivity does not necessarily undermine Christian values, but rather can mirror the gospel message of equality before God. In other words this shift provides a suitable context for Christian values. However, such an approach requires exposing modernist essentialism with regard to sexuality.

The postmodern philosopher Michel Foucault (1978), in his work, History of sexuality, maintains that there is no a-historical "truth about sex" (see also Foucault 1988:77). He further points out that complex power/knowledge mechanisms are operative in the discourses of sexuality. It is not only about the suppression or liberation of sexuality as such, or of some forms of sexual expression. It is also about how sexuality can be used in other areas which ostensibly have nothing to do with sex, in order to stereotype specific groups and so reinforce their inequality: “... it is the specification of interrelations between sexuality and supposedly nonsexual phenomena, rather than the restriction of sexuality to biological and physiological processes, that has become key to postmodern analyses of sexuality" (Stone 2000:236). Stone (2000:236) cites "racial" and ethnic inequality as an example and expresses the concern that some biblical scholars might even be reinforcing this by means of their exegetical work (see Stone 2000).

The Eastern Mediterranean notion that sex was chiefly meant for procreation remained prevalent throughout the medieval period because of it being supported by Catholicism, both in the Roman and Orthodox traditions. During the period of the Reformation some changes regarding the interconnections between sexuality, religion and marriage took place. Marriage was absolutised on account of Protestant emphasis on "covenantal theology" (cf Van Wyk 2002:270). In this view marriage was (and is) seen as the only "proper place" for practising sexuality. Daan van Wyk jr (2002:275) formulates it as follows (my translation from the Afrikaans):

A denomination in the Biblical-Reformed tradition that would like to take the Bible seriously as primary normative source cannot but see monogamous marriage as positioned in the Bible as the only model according to which one man and one woman should be together in a lifelong relationship. The foundation of marriage is based on the relationship between husband and wife to God. On the grounds of this relationship husband and wife know that man and woman have been created for each other because God does not want them to be alone [as individuals].

Seen thus, marriage is more of a "covenant" than a "contract". The concept "covenant", also according to Adrian Thatcher (1999: 68) is the "biblical model" for marriage. However, using such a "biblical model" in a normative 


\section{Sexuality and shifting paradigms - setting the scene}

and prescriptive way comes down to a modernist, essentialist view of Scripture. It uses the Bible in a "naïve-realistic" manner, seeing the Bible as an objective divine revelation from above. Yet, epistemologically seen, "understanding the Bible as a religious text naïve realism has rather grim implications: the Biblical text as a reality is of course very much stressed but then as a closed reality in which the reader has to search for the meaning that the historical writer has put there once and for all' (Van Huyssteen 1987:20; emphasis by Van Huyssteen). According to Wentzel van Huyssteen (1987:19), "[i]n theology every possible form of fundamentalism would be covered by this model."

During the modern era traditional ideas such as that of the "marriage covenant", were slowly eroded by the process of secularisation, which was set in motion by Romanticism. According to the romantic view, sexuality was to express and strengthen emotional bonds, intimacy and friendship. The "libertarian" idea went even further than that. Pleasure derived from sexual activity had value in itself and should not necessarily be restricted to contexts where emotional ties exist. The only "norm" for sexuality should be mutual consent. However opposing they may be, both traditionalist and romantic attitudes have influenced faith communities. Libertarian notions, on the other hand, were rejected. Both the traditionalist and the romantic ideas lead to a reduction of sexuality (cf Seidman 1992). According to Stone (2000:238), "[t]raditionalism and romanticism tend toward an essentialist view of sexuality in which its significance is thought to be inherent within certain acts or practices, irrespective of context, effects, or the intentions of the actors". Traditionalism and romanticism are prescriptive and "normative" in their approach to sexuality. Such an approach does not adequately take into account the great variety of meanings and experiences related to sexuality.

In contrast to the above three approaches, postmodern sexual ethics would rather value pluralism and diversity and would emphasize the contexts when analysing and interpreting specific sexual activities. However, this postmodern approach is not devoid of norms and values and is not "relativistic" (cf Müller \& Pienaar 2003:141; contra Van Wyk 2002:279), though the norms and values are seen as "contingent on and relative to the times, places, and populations in relation to which they are elaborated" (Stone 2000:238; cf Seidman 1992; Weeks 1997).

\section{CONTEXTUALISED REVELATION - POSTSCRIPT WITH AN OPEN END}

Understanding contingency is relevant for the interpretation of inscripturation (the codification of social values). When the interconnectivity of sexuality, 
religion and marriage is codified in Biblical writings, the temptation is to equate this codification with divine revelation. Revelation, however, also takes place within specific contexts. Richard Horsley (2003:70) puts it as follows:

In a relational-contextual and communications approach, revelation would have to be understood relationally-historically. Revelation would be not something new in itself, but would be revelation about the historical situation to people in that situation, for example, the difficult crisis that people are facing, with no resolution apparent. Revelation was that God was acting to change the situation and to change the people in that situation, so that they can act ....

Exegesis identifies the values expressed in the specific contexts. In today's postmodern world exegetes apply critical theories from the social sciences to indicate how Scripture forms part of the canonisation process. Critical theories also revealed to what extent sexuality as a social construct was determined by a male perspective.

If there is an awareness of change in social life, theologians and exegetes in particular should consider the reality of vast differences from the contexts of Eastern Mediterranean, Western Mediterranean, medieval, Catholic, Protestant, to modern and postmodern worlds. If one agrees with the postmodern notion that sexuality is not homogeneous, but the result of an endless variety of ever varying factors, then the logical consequence will be to acknowledge that different times and different societies will produce different sexual practices, experiences, values and meanings and that these will always be changing. Sociological, cultural and technological changes forever taking place at a rapid pace, will keep widening the gap between our times and that of the Bible, between our notions of sexuality and those of the Bible. The challenge today is to find a spiritual ethos according to which people can live with the biblical message of redemption in the presence of God within the context of the faith community but without blind submission to outdated social constructs.

\section{Works consulted}

Adam, A K M (ed) 2000. Handbook of postmodern biblical interpretation. St Louis, MO: Chalice Press.

Allen, D 2000. The world of Prometheus: The politics of punishment in democratic Athens. Princeton, NJ: Princeton University Press.

Berger, P L \& Luckmann, T 1967. The social construction of reality: $A$ treatise in the sociology of knowledge. New York: Doubleday. 


\section{Sexuality and shifting paradigms - setting the scene}

Beukes, C J 2002. Ars erotica and the detrivialization of the sexual discourse: An annotation to Michel Foucault's analysis of sexuality (article originally written in Afrikaans). HTS 58(1), 283-298.

Bland, L \& Doan, L (eds) 1998. Sexology in culture: Labelling bodies and desires. Chicago, IL: University of Chicago Press.

Blumenfeld, W J (ed) [1992] 2001. Homophobia - How we all pay the price. Boston, MA: Beacon Press.

Borg, M J 1987. Jesus: A new vision - spirit, culture, and the life of discipleship. San Francisco, CA: HarperSanFrancisco.

Bossman, D 1979. Ezra's marriage reform: Israel redefined. Biblical Theology Bulletin 9, 32-38.

Boswell, J 1980. Christianity, social tolerance and homosexuality: Gay people in Western Europe from the beginning of the Christian Era to the fourteenth century. Chicago, IL: Chicago University Press.

Boswell, J 1994. Same-sex unions in premodern Europe. New York: Villard Books.

Brown, J 2004. God, gender and biblical metaphor, in Pierce, R W \& Groothuis, R M (eds) (with Fee, G D as contributing editor), Discovering biblical equality: Complementarity without hierarchy, 287-300. Leicester: Inter-Varsity Press.

Burton, R V \& Whiting, J W M 1961. The absent father and cross-sex identity. MerrillPalmer Quarterly 7, 85-95.

Cameron, A \& Kuhrt, A (eds) 1983. Images of women in antiquity. London: Croom Helm.

Cantarella, E 1987. Pandora's daughters: The role and status of women in Greek and Roman antiquity. Baltimore, MD: The Johns Hopkins University Press.

Cantarella, E 2002. Bisexuality in the ancient world, tr by C O'Cuilleanain. New Haven, KY: Yale University Press.

Caplan, $\mathrm{P}$ et al 1987. The cultural construction of sexuality. New York: Routledge.

Cohen, D 1991. Law, sexuality and society: The enforcement of morals in Classical Athens. Cambridge: Cambridge University Press.

Cole, S G 1984. Greek sanctions against sexual assault. Classical Philology 79.

Dean-Jones, L 1994. Women's bodies in classical Greek science. Oxford: Clarendon Press.

D'Emilio, J \& Freedman, E W 1997. Intimate matters: A history of sexuality in America. $2^{\text {nd }}$ edition. Chicago, IL: University of Chicago Press.

Dreyer, $Y$ 2002. Leadership in the world of the Bible: (De)institutionalisation as an ongoing process. Verbum et Ecclesia 23(3), 625-641.

Du Plessis, T 2005. Wat Zuma, Gaum gemeen het: Albei se instellings worstel met verandering. Rapport 4 September 2005, p IVNuus.

Elliott, J H 1991. Household and meals versus the Temple purity system: Patterns of replication in Luke-Acts. Biblical Theology Bulletin 21(3), 102-108.

Fiensy, D A 1991. The social history of Palestine in the Herodian period: The land is mine. Lewiston, NY: Edwin Mellen Press. (Studies in the Bible and Early Christianity 20.)

Foley, H P (ed) 1981. Reflections of women in antiquity. New York: Gordon and Breach.

Foucault, M [1976] 1978. The history of sexuality, Vol 1: An introduction, tr by R Hurley. New York: Random House. 
Foucault, M 1988. Truth, power, self: An interview with Michel Foucault, October 25, 1982, in Martin, L H \& Goodman, H \& Hutton, P H (eds), Technologies of the self: A seminar with Michel Foucault, 9-15. Amherst, MA: University of Massachusetts Press.

Foxall, L 1998. Pandora unbound: A feminist critique of Foucault's History of Sexuality, in Larmour, D H J, Miller, P A \& Platter, C (eds), Rethinking sexuality. Princeton, NJ: Princeton University Press.

Freud, S 1938. Infantile sexuality, in The basic writings of Sigmund Freud, tr by A A Brell. New York: Modern Library.

Gagnon, J \& Simon, W 1973. Sexual conduct: The social sources of human sexuality. Chicago, IL: Aldine Publishing.

Garton, S 2004. Histories of sexuality: Antiquity to sexual revolution. London: Equinox Publishing. (Critical Histories of Subjectivity and Culture.)

Giddens, A 1992. The transformation of intimacy: Sexuality, love and eroticism in modern societies. Stanford, CA: Stanford University Press.

Gleason, M W 1990. The semiotics of gender: Physiognomy and self-fashioning in the second century, in Halperin, D M, Winkler, J J \& Zeitlin, F I (eds), Before sexuality: The construction of erotic experience in the Ancient Greek world, 389-415. Princeton, NJ: Princeton University Press.

Gleason, M W 1995. Making men: Sophists and self-presentation in Ancient Rome. Princeton, NJ: Princeton University Press.

Halperin, D M 1990. One hundred years of homosexuality and other essays on Greek love. New York: Routledge.

Halperin, D M 1998a. Homosexuality, in Hornblower, S \& Spawforth, A (eds), Oxford Companion to Classical Civilisation, 353-354 Oxford: Oxford University Press.

Halperin, D M 1998b. Forgetting Foucault: Acts, identities and the History of Sexuality. Representations 63, 93-120.

Halperin, D M 2002. How to do the history of homosexuality. Chicago, IL: University of Chicago Press.

Hamerton-Kelly, R 1979. God the Father: Theology and patriarchy in the teaching of Jesus. Philadephia, PA: Fortress. (Overtures to Biblical Theology.)

Harper, M 1928. Village administration in the Roman province of Syria. Yale Classical Studies 1, 105-168.

Herdt, G 1997 (ed). Same sex, different cultures. Boulder: Westview Press.

Horsley, R A 2003. Jesus and the Empire: The kingdom of God and the new world disorder. Minneapolis, MN: Augsburg Fortress.

Jeremias, J 1969. Jerusalem in the time of Jesus: An investigation into economic and social conditions during the New Testament period, tr by F H \& C H Cave from the third German edition. London: SCM.

King, H 1998. Hippocrates' women: Reading the female body in Ancient Greece. London: Routledge.

Kinsey, A, Pomeroy, W \& Martin, C 1948. Sexual behavior in the human male. Philadelphia, PA: W B Saunders.

Lacqueur, T 1990. Making sex: Body and gender from the Greeks to Freud. Cambridge, MA: Harvard University Press.

Lenski, G, Lenski, J \& Nolan, P [1970] 1995. Human societies: An introduction to macrosociology. $7^{\text {th }}$ edition. New York: McGraw-Hill. 


\section{Sexuality and shifting paradigms - setting the scene}

Malina, B J 1993. The New Testament world: Insights from cultural anthropology. Revised edition. Louisville, KY: Westminster.

Malina, B J 1996. The question of first-century Mediterranean persons, in Malina, B J, The social world of Jesus and the Gospels, 35-66. London: Routledge \& Kegan Paul.

Marcus, S 1966. The other Victorians: A study of sexuality and pornography in midnineteenth century England. New York: Basic Books.

Matthews, V C \& Benjamin, D C 1993. Social world of ancient Israel 1250-587 BCE. Peabody, MA: Hendrickson.

Müller, J C \& Pienaar, H E 2003. A social-constructionist, narrative understanding of the church's morality on sex. Verbum et Ecclesia 24(1), 137-155.

Nelson, J B 1992. The intimate connection: Male sexuality, masculine spirituality. Philadelphia, PA: Westminster Press.

Neusner, J 1973. From politics to piety. Englewood Cliffs, NJ: Prentice Hall.

Neusner, J 1979. The way of Torah: An introduction to Judaism. North Scituate, MA: Duxbury Press.

Nicholson, M 1999. Male envy: The logic of malice in literature and culture. Lanham: Lexington Books.

Padgug, R 1992. Sexual matters: On conceptualizing sexuality in history, in Stein, E (ed), Forms of desire: Sexual orientation and the social constructionist controversy, 43-67. New York: Routledge.

Peis, K \& Simmonds, C (eds) 1989. Passion and power: Sexuality in history. Philadelphia, PA: Temple University Press.

Pellegrini, A [1992] 2001. S(h)ifting the terms of hetero/sexism: Gender, power, homophobias, in Blumenfeld, $\mathrm{W} \mathrm{H}$ (ed), Homophobia: How we all pay the price, 39-56. First digital-print edition. Boston, MA: Beacon Press.

Rawson, B (ed) 1992. The family in ancient Rome: New perspectives. London: Croom Helm.

Richlin, A 1992a. The garden of Priapus: Sexuality and aggression in Roman Humour, $2^{\text {nd }}$ edition. New York: Oxford University Press.

Richlin, A 1992b. Pornography and representation in Greece and Rome. New York: Oxford University Press.

Richlin, A 1993. Not before homosexuality: The materiality of cinaedus and the Roman law against love between men. Journal of the History of Sexuality 3(4), 523-573.

Robinson, P 1996. The modernization of sex. New York: Harper \& Row.

Sanders, E P 1993. The historical figure of Jesus. New York: Allen Lane Penguin.

Scott, B B 1990. Hear then the parable: A commentary on the parables of Jesus. Minneapolis, MN: Fortress.

Seidman, S 1990. Romantic longings. New York: Routledge.

Seidman, S 1992. Embattled eros: Sexual politics and ethics in contemporary America. New York: Routledge.

Shields, M E 2001. An abusive God? Identity and power/gender and violence in Ezekiel 23, in Adam, A K M (ed), Postmodern interpretations of the Bible - A reader, 129-151. St Louis, MO: Chalice Press.

Simon. W 1996. Postmodern sexualities. New York: Routledge.

Stone, K 2000. Sexuality, in Adam, A K M (ed), Handbook of postmodern biblical interpretation. St Louis, MO:Chalice Press. 
Thatcher, A 1999. Marriage after modernity: Christian marriage in postmodern times. Sheffield: Sheffield Academic Press. (Studies in Theology and Sexuality 3.)

Thorpe, J 1992. The social construction of homosexuality. Phoenix 46, 54-61.

Tillich, P 1957. Systematic theology, vol 2. Chicago, IL: Chicago University Press.

Vance, C 1989. Social construction theory: Problems in history of sexuality, in Altman, D et al, Homosexuality, Which homosexuality? Amsterdam: Uitgeverij An Dekker.

Vance, C 1991. Anthropology rediscovers sexuality: A theoretical comment. Social Science and Medicine 33(8), 875-884.

Van Huyssteen, W 1987. The realism of the text: A perspective on biblical authority, edited by Pieter G R de Villiers. Pretoria: University of South Africa. (C B Powell Public Lectures.)

Van Wyk, D J C jr 2002. Marriage and sexuality in a postmodern society (article originally written in Afrikaans). HTS 58(1), 264-282.

Veyne, P 1985. Homosexuality in ancient Rome, in Aries, P \& Béjin (eds), Western sexuality: Practice and precept in past and present times, 26-35. Oxford: Basil Blackwell.

Von Rad, G [1964] 1966. Deuteronomy: A commentary, tr by D Barton. London: SCM Press. (The Old Testament Library.)

Ward, G 1997. Postmodernism. London: Hodder Headline. (Teach Yourself.)

Weeks, J 1985. Sexuality and its discontents: Meanings, myths and modern sexualities. Londen: Routledge \& Kegan Paul.

Weeks, J 1986. Sexuality. London: Routledge.

Weeks, J 1989. Sex, politics and society: The regulation of sexuality since 1800. London: Longman.

Williams, C A 1999. Roman homosexuality: Ideologies of masculinity in classical antiquity. New York: Oxford University Press.

Winkler, J J 1990. The constraints of desire: The anthropology of sex and gender in ancient Greece. New York: Routledge.

Wolf, E R 1966. Peasants. Englewood Cliffs, NJ: Prentice Hall. 